\title{
FAKTOR-FAKTOR YANG MEMPENGARUHI PERKEMBANGAN PARIWISATA PANTAI DI KABUPATEN PURWOREJO
}

\author{
Sri Rahayu Febrianingrum¹, Nur Miladan1, Hakimatul Mukaromah'1 \\ 1Program Studi Perencanaan Wilayah dan Kota Fakultas Teknik Universitas Sebelas Maret Surakarta
}

\begin{abstract}
Abstrak
Kabupaten Purworejo memiliki pantai yang dijadikan sebagai destinasi wisata yaitu Pantai Jatimalang, Pantai Keburuhan dan Pantai Ketawang Indah yang ditetapkan sebagai desa wisata. Pariwisata pantai di Kabupaten Purworejo telah dibuka dan dikelola sejak tahun 2006. Pendapatan daerah Kabupaten Purworejo pada sektor pariwisata sebagian besar berasal dari pariwisata pantai namun hingga saat ini belum terlihat peningkatan dalam pemenuhan infrastruktur pendukung pariwisata dan elemen-elemen pariwisata yang lain di setiap pariwisata pantai. Penelitian ini bertujuan untuk mengetahui faktor apa saja yang mempengaruhi perkembangan pariwisata pantai di Kabupaten Purworejo. Pada penelitian ini menggunakan pendekatan deduktif. Metode pengumpulan data menggunakan observasi, random sampling untuk kuesioner, wawancara dengan purposive sampling dan studi dokumen. Untuk mengetahui tingkat kepentingan aspek dan faktor apa saja yang berpengaruh maka digunakan teknik analisis skoring. Hasil dari penelitian ini terkait dengan faktor pendorong dalam perkembangan pariwisata pantai adalah ketersediaan jaringan jalan yang memadai, kedekatan destinasi wisata terhadap asal wisatawan, peran aktif masyarakat dan keamanan pada destinasi wisata. Faktor yang menghambat dalam perkembangan pariwisata pantai meliputi, keterbatasan pemenuhan sarana dan prasarana, ketidaklengkapan sarana pelabuhan perikanan, ketidakintegrasian moda transportasi umum antar pariwisata pantai, ketidakoptimalan peran lembaga pengelola pariwisata dan ketidakoptimalan pemanfaatan media untuk promosi wisata. Untuk faktor moderat yaitu adanya variasi atraksi wisata, keanekaragaman hayati sebagai daya tarik wisata, pelayanan baik pelaku usaha terhadap wisatawan, ketersediaan fasilitas kebencanaan pesisir dan tindakan mitigasi bencana pesisir pantai.
\end{abstract}

Kata kunci: faktor perkembangan pariwisata pantai; pariwisata pantai; perkembangan pariwisata

\begin{abstract}
Purworejo Regency had some beaches that served as a tourist destination. Those beaches were Jatimalang Beach, Keburuhan Beach and Ketawang Indah Beach and designated as a tourist village. Beach tourism in Purworejo Regency has been opened and managed since 2006. The revenue of Purworejo Regency in the tourism sector mostly comes from coastal tourism but until now there isn't any improvement in the fulfillment of tourism infrastructure supporting and othertourism elements in every beach tourism. This study aims to determine what factors affect the development of beach tourism in Purworejo Regency. This study used deductive approach. Data collection methods using observation, random sampling for questionnaires, interviews with purposive sampling and document studies. To know the level of importance of any aspect and factors that influenced it, scoring analysis technique was used. The results of this study related to the driving factors in the development of beach tourism was the availability of adequate road network, the proximity of tourist destinations to the origin of tourists, the active role of the community and security in tourist destinations. Factors that hinder the development of beach tourism were limited fulfillment of facilities and infrastructure, incomple fishing port facilities, public transportation modes between beach tourism wasn't integrated, unoptimal role of tourism management institutions and lack of media utilization for tourism promotion. As for the moderate factor was variation of tourist attractions, natural biodiversity as a tourist attraction, good service of business actors to tourists, availability of beach disaster facilities and beach disaster mitigation action.
\end{abstract}

Keywords: beach tourism; beach tourism development factors; tourism development

\section{PENDAHULUAN}

Pada saat ini kegiatan pariwisata menjadi kebutuhan masyarakat karena merupakan kegiatan untuk berekreasi dan menenangkan diri. Terdapat elemen-elemen yang harus dipenuhi oleh suatu destinasi wisata, yaitu atraksi, fasilitas, infrastruktur, transportasi, dan keramahtamahan (Spillane dalam Tahir 2005). Salah satu jenis wisata merupakan wisata alam. Wisata alam yang berupa wisata pantai merupakan wisata yang diminati oleh masyarakat karena biasanya relatif masih alami dan jauh dari kebisingan perkotaan sehingga memberikan rasa nyaman pada wisatawan. 
Kabupaten Purworejo yang terletak di selatan Provinsi Jawa Tengah memiliki pantai-pantai yang dijadikan sebagai destinasi wisata yang ditetapkan sebagai desa wisata dan dikelola sejak tahun 2006 yaitu Pantai Jatimalang, Pantai Keburuhan dan Pantai Ketawang Indah. Sebagai destinasi wisata seharusnya elemen-elemen pariwisata sudah terpenuhi mengingat destinasi wisata ini sudah lama dibuka dan dikelola. Berdasarkan Renstra Dinas Koperasi Perindustrian Perdagangan dan Pariwisata Kabupaten Purworejo tahun 2010-2014, Pendapatan Asli Daerah sektor pariwisata sebesar $40 \%$ berasal dari pariwisata pantai. Namun pada ketiga pantai ini belum terlihat adanya pemenuhan elemen-elemen pariwisata yang mendorong perkembangan pariwisata pantai. Berdasarkan hal tersebut maka diajukan penelitian yang berjudul "Faktor-Faktor yang Mempengaruhi Perkembangan Pariwisata Pantai di Kabupaten Purworejo". Penelitian ini bertujuan untuk mengetahui faktor apa saja yang mempengaruhi perkembangan pariwisata pantai di Kabupaten Purworejo, meliputi faktor pendorong, faktor penghambat dan faktor moderat.

\section{KAJIAN LITERATUR}

Faktor merupakan suatu hal yang mempengaruhi terjadinya sesuatu (KBBI Daring Edisi III). Perkembangan merupakan perubahan yang tidak hanya bersifat kuantitatif namun juga kualitatif, selain itu perkembangan adalah perubahan yang progresif dan koheren. Progresif adalah perubahan yang terarah dan koheren menunjukkan adanya perubahan yang nyata antara sebelum atau sesudahnya (Perdana, 2015). Disimpulkan faktor perkembangan pariwisata pantai merupakan hal atau kondisi yang berpengaruh dalam perkembangan pariwisata pantai dimana perkembangan tersebut terarah dan dapat lihat perubahan antara sebelum perkembangan dan sesudah perkembangan. Dalam faktor yang mempengaruhi perkembangan pariwisata pantai terdapat faktor yang mendorong perkembangan pariwisata pantai dan faktor yang menjadi penghambat dalam perkembangan pariwisata pantai. Berikut merupakan penjelasan mengenai faktor apa saja yang dapat mempengaruhi perkembangan pariwisata pantai.

Tabel 1. Variabel Penelitian

\begin{tabular}{|c|c|c|c|}
\hline Aspek & Variabel & Penjelasan & Sumber \\
\hline \multirow{2}{*}{$\begin{array}{l}\text { Atraksi } \\
\text { Wisata }\end{array}$} & Jenis aktivitas & $\begin{array}{l}\text { Wisata pantai merupakan wisata yang menempatkan pantai dan } \\
\text { lingkungannya sebagai daya tarik, beberapa atraksi wisata yang terdapat } \\
\text { dipantai yaitu olahraga pantai, konservasi, kualitas pemandangan dan } \\
\text { spot fotografi yang menarik }\end{array}$ & $\begin{array}{l}\text { Fandeli dalam } \\
\text { Latupapua, } 2011\end{array}$ \\
\hline & $\begin{array}{l}\text { Keaneka- } \\
\text { ragaman } \\
\text { hayati di } \\
\text { pantai }\end{array}$ & $\begin{array}{l}\text { Pantai adalah tempat yang unik karena merupakan pertemuan daratan } \\
\text { dan lautan sehingga memiliki keanekaragaman hayati di darat dan laut } \\
\text { yang beragam. }\end{array}$ & $\begin{array}{l}\text { Fandeli dalam } \\
\text { Latupapua, } 2011\end{array}$ \\
\hline \multirow{4}{*}{ Infrastruktur } & $\begin{array}{l}\text { Sarana dasar } \\
\text { pariwisata }\end{array}$ & \multirow{2}{*}{$\begin{array}{l}\text { Wisatawan memerlukan fasilitas wisata (sarana dan prasarana) untuk } \\
\text { memenuhi kebutahannya selama berada di destinasi wisata sehingga } \\
\text { kelengkapan fasilitas wisata dan kualitas pelayanan dalam fasilitas } \\
\text { tersebut diperlukan untuk mendorong perkembangan pariwisata. }\end{array}$} & \multirow[t]{2}{*}{ Yoeti, 1996} \\
\hline & $\begin{array}{l}\text { Prasarana } \\
\text { dasar } \\
\text { pariwisata }\end{array}$ & & \\
\hline & $\begin{array}{l}\text { Fasilitas } \\
\text { terkait } \\
\text { kebencanaan } \\
\text { pada kawasan } \\
\text { pantai }\end{array}$ & $\begin{array}{l}\text { Di daerah pantai, pesisir dan pulau-pulau kecil merupakan daerah yang } \\
\text { rawan bencana alam seperti gempa, banjir pasang dan angin besar } \\
\text { sehingga diperlukan fasilitas kebencanaan untuk meminimalisir adanya } \\
\text { korban. }\end{array}$ & $\begin{array}{l}\text { Ongkosongo, } \\
2004\end{array}$ \\
\hline & $\begin{array}{l}\text { Fasilitas } \\
\text { pelabuhan } \\
\text { perikanan } \\
\text { pantai }\end{array}$ & $\begin{array}{l}\text { Jenis penggunaan lahan yang ada dipantai biasanya berupa infrastruktur, } \\
\text { wisataserta konservasi. Salah satu sumber daya yang ada yaitu sumber } \\
\text { daya perikanan. Hal ini dikarenakan pantai berbatasan langsung dengan } \\
\text { laut sehingga dijadikan tempat dalam pendaratan ikan. }\end{array}$ & $\begin{array}{l}\text { Kay dalam } \\
\text { Sugandi, } 2011\end{array}$ \\
\hline \multirow[t]{2}{*}{ Aksesibilitas } & Jaringan Jalan & $\begin{array}{l}\text { Prasarana transportasi yang utama yang digunakan wisatawan untuk } \\
\text { mencapai destinasi wisata adalah jaringan jalan yang menghubungkan } \\
\text { antar obyek dan atraksi wisata. Apabila kondisi jaringan jalan yang baik } \\
\text { yang disertai dengan rambu penunjuk arah yang baik maka semakin } \\
\text { mempermudah wisatawan untuk menuju ke destinasi wisata. }\end{array}$ & $\begin{array}{l}\text { French dalam } \\
\text { Sunaryo, } 2013\end{array}$ \\
\hline & $\begin{array}{l}\text { Posisi } \\
\text { Geografis / } \\
\text { Lokasi }\end{array}$ & $\begin{array}{l}\text { Aksesibilitas dipengaruhi oleh posisi geografis destinasi wisata mengenai } \\
\text { hubungan antara segmen pasar dan destinasi pariwisata menurut fungsi } \\
\text { jarak dan waktu. }\end{array}$ & $\begin{array}{l}\text { Rai dan } \\
\text { Mahadewi, } 2012\end{array}$ \\
\hline
\end{tabular}




\begin{tabular}{|c|c|c|c|}
\hline Aspek & Variabel & Penjelasan & Sumber \\
\hline & $\begin{array}{l}\text { Moda } \\
\text { Transportasi } \\
\text { Umum }\end{array}$ & $\begin{array}{l}\text { Kemajuan bidang transportasi atau pengangkutan sangat dibutuhkan } \\
\text { karena hal ini menyangkut jarak dan waktu tempuh dalam } \\
\text { perjalanan wisata. }\end{array}$ & $\begin{array}{l}\text { Spillane dalam } \\
\text { Tahir, } 2005\end{array}$ \\
\hline \multirow[t]{2}{*}{ Kelembagaan } & $\begin{array}{l}\text { Lembaga } \\
\text { pengelola }\end{array}$ & $\begin{array}{l}\text { Kelembagaan pariwisata merupakan kesatuan unsur dan jaringan yang } \\
\text { dikembangkan secara terorganisir meliputi pemerintah, pemerintah } \\
\text { daerah, swasta dan masyarakat secara berkesinambungan agar } \\
\text { mencapai tujuan pariwisata. }\end{array}$ & $\begin{array}{l}\text { PP Nomor } 50 \\
\text { Tahun } 2011 \\
\text { tentang Rencana } \\
\text { Induk } \\
\text { Pembangunan } \\
\text { Pariwisata } \\
\text { Nasional Tahun } \\
2010-2025\end{array}$ \\
\hline & Promosi & $\begin{array}{l}\text { Destinasi wisata membutuhkan agen perjalanan wisata serta promosi } \\
\text { untuk menarik pengunjung. }\end{array}$ & $\begin{array}{l}\text { Gunn dan Turgut } \\
\text { dalam Aristrawati, } \\
2015\end{array}$ \\
\hline $\begin{array}{l}\text { Partisipasi } \\
\text { masyarakat }\end{array}$ & $\begin{array}{l}\text { Partisipasi } \\
\text { masyarakat }\end{array}$ & $\begin{array}{l}\text { Masyarakat memiliki peran penting dalam pembangunan pariwisata. } \\
\text { Pembangunan pariwisata sulit diwujudkan apabila masyarakat lokal } \\
\text { merasa diabaikan serta merasa terancam oleh kegiatan pariwisata } \\
\text { tersebut }\end{array}$ & $\begin{array}{l}\text { Sugiarti dalam } \\
\text { Mahagangga, } \\
2015\end{array}$ \\
\hline \multirow[t]{4}{*}{$\begin{array}{l}\text { Keramah- } \\
\text { tamahan }\end{array}$} & $\begin{array}{l}\text { Pelayanan } \\
\text { pelaku usaha }\end{array}$ & $\begin{array}{l}\text { Bagaimana pelaku usaha menyediakan fasilitas untuk memenuhi } \\
\text { kebutuhan wisatawan dan kualitas pelayanan yang baik kepada } \\
\text { wisatawan. }\end{array}$ & Prawinata, 2016 \\
\hline & $\begin{array}{l}\text { Keamanan } \\
\text { sosial } \\
\text { wisatawan }\end{array}$ & Seberapa sering terjadi tindak kejahatan di kawasan pariwisata & Susanti, 2010 \\
\hline & \multirow{2}{*}{$\begin{array}{l}\text { Keamanan } \\
\text { terhadap } \\
\text { bencana / } \\
\text { Mitigasi } \\
\text { bencana }\end{array}$} & $\begin{array}{l}\text { Tingkat kerawanan bencana pada suatu kawasan wisata mempengaruhi } \\
\text { perkembangan pariwisata karena apabila terjadi bencana dapat } \\
\text { menimbulkan kerugian. }\end{array}$ & Rosyidie, 2004 \\
\hline & & Upaya yang dilakukan untuk mengurangi resiko bencana tersebut & Bappenas, 2006 \\
\hline
\end{tabular}

\section{METODOLOGI PENELITIAN}

\subsection{Pendekatan dan Jenis Penelitian}

Pendekatan penelitian secara deduktif yang diawali dengan teori terkait perkembangan pariwisata pantai kemudian teori tersebut dibuktikan dengan fenomena di lapangan. Pendekatan penelitian ini didasarkan dari adanya fenomena pariwisata pantai di Kabupaten Purworejo yang berpotensi sebagai pariwisata pantai namun hingga saat ini belum terlihat pemenuhan elemen pariwisata untuk mendorong perkembangan pariwisata pantai. Jenis penelitian ini adalah penelitian kuantitatif. Penelitian kuantitatif adalah penelitian yang proses menemukan kebenarannya menggunakan variabel yang dapat diukur sehingga dapat dioperasionalkan dan data tersebut dianalisis dengan teknik analisis statistik.

\subsection{Variabel Penelitian}

Tabel 2. Variabel Operasional Penelitian

\begin{tabular}{|l|l|l|l|}
\hline & \multicolumn{1}{|c|}{ Variabel } & \multicolumn{1}{c|}{ Indikator } & \multicolumn{1}{c|}{ Sumber } \\
\hline \multirow{5}{*}{ Atraksi Wisata } & Jenis aktivitas & $\begin{array}{l}\text { Semakin banyak jenis aktivitas yang ada di kawasan pariwisata } \\
\text { dapat menambah daya tarik. } \\
\text { - Olahraga pantai } \\
\text { - Kualitas pemandangan } \\
\text { - Konservasi } \\
\text { - Ada spot fotografi yang menarik }\end{array}$ & $\begin{array}{l}\text { Fandeli dalam } \\
\text { Latupapua, } 2011\end{array}$ \\
\cline { 2 - 5 } & $\begin{array}{l}\text { Keanekaragaman } \\
\text { hayati di pantai }\end{array}$ & $\begin{array}{l}\text { Semakin banyak flora dan fauna (darat maupun air) yang } \\
\text { beragam maka akan menambah daya tarik dan mengindikasikan } \\
\text { pantai masih belum tercemar. }\end{array}$ & $\begin{array}{l}\text { Fandeli dalam } \\
\text { Latupapua, } 2011\end{array}$ \\
\hline
\end{tabular}




\begin{tabular}{|c|c|c|c|}
\hline & Variabel & Indikator & Sumber \\
\hline \multirow{4}{*}{ Infrastruktur } & $\begin{array}{l}\text { Sarana dasar } \\
\text { pariwisata }\end{array}$ & $\begin{array}{l}\text { Sarana rumah makan, penginapan, toilet, mushola, sarana } \\
\text { kesehatan, bank/atm, area parkir, keamanan dan loket diukur } \\
\text { secara kuantitas dan kualitas. } \\
\text { - Kuantitas yaitu jumlah sarana yang tersedia } \\
\text { - Kualitas dilihat dari kondisi, mutu pelayanan dan kepuasan } \\
\text { wisatawan dalam memperoleh pelayanan }\end{array}$ & $\begin{array}{l}\text { Yoeti, } 1996 \\
\text { Sunaryo, } 2013\end{array}$ \\
\hline & $\begin{array}{l}\text { Prasarana dasar } \\
\text { pariwisata }\end{array}$ & $\begin{array}{l}\text { Jaringan air bersih, jaringan listrik, jaringan drainase, jaringan } \\
\text { persampahan dan jaringan telekomunikasi diukur secara } \\
\text { kuantitas dan kualitas. } \\
\text { - Kuantitas yaitu prasarana yang tersedia } \\
\text { - Kualitas dilihat dari kondisi, mutu pelayanan dan kepuasan } \\
\text { wisatawan dalam memperoleh pelayanan } \\
\end{array}$ & Yoeti, 1996 \\
\hline & $\begin{array}{l}\text { Fasilitas terkait } \\
\text { kebencanaan } \\
\text { pada kawasan } \\
\text { pantai }\end{array}$ & $\begin{array}{l}\text { Terdapat peringatan dini berupa fasilitas peringatan waspada } \\
\text { gempa tsunami dengan kondisi fasilitas yang baik, jalur evakuasi } \\
\text { bencana, titik kumpul evakuasi bencana dan fasilitas peringatan } \\
\text { waspada gempa tsunami dengan kondisi fasilitas yang baik }\end{array}$ & $\begin{array}{l}\text { Permen PU Nomor } \\
\text { 06/PRT/M/2009 }\end{array}$ \\
\hline & $\begin{array}{l}\text { Fasilitas } \\
\text { pelabuhan } \\
\text { perikanan pantai }\end{array}$ & $\begin{array}{l}\text { Terdapat breakwater, dermaga, pelabuhan perikanan, tempat } \\
\text { pelelangan ikan, pengolahan limbah (IPAL), Kantor Administrasi } \\
\text { Pelabuhan, Balai Pertemuan Nelayan dan menara pengawas } \\
\text { dengan kondisi yang baik }\end{array}$ & $\begin{array}{l}\text { Kep.10/Men/2004 } \\
\text { tentang Pelabuhan } \\
\text { Perikanan Pantai }\end{array}$ \\
\hline \multirow{4}{*}{ Aksesibilitas } & \multirow[t]{2}{*}{ Jaringan jalan } & $\begin{array}{l}\text { - Jalan lokal dengan lebar jalan 3m-7m, jalan diaspal dengan } \\
\text { kondisi baik } \\
\text { - Jalan lingkungan/jalan lain dengan lebar jalan } 2 \mathrm{~m}-5 \mathrm{~m} \text {, jalan } \\
\text { diaspal dan kondisi baik } \\
\text { - Jalan setapak dengan lebar jalan } 0,8 \mathrm{~m}-2 \mathrm{~m} \text {, berupa paving } \\
\text { dan kondisi baik }\end{array}$ & \multirow{2}{*}{$\begin{array}{l}\text { PP Nomor } 34 \text { Tahun } \\
2006 \text { tentang Jalan } \\
\text { (Keputusan Menteri } \\
\text { Permukiman dan } \\
\text { Prasarana Wilayah } \\
\text { No. } \\
\text { 534/KPTS/M/2001 }\end{array}$} \\
\hline & & $\begin{array}{l}\text { Terdapat rambu penunjuk arah dengan kondisi yang baik dan } \\
\text { dapat terbaca secara jelas }\end{array}$ & \\
\hline & $\begin{array}{l}\text { Posisi geografis / } \\
\text { lokasi }\end{array}$ & $\begin{array}{l}\text { Wisatawan menuju destinasi wisata dengan jarak dan waktu } \\
\text { tempuh yang normal } \\
-24 \mathrm{~km}-80 \text { dengan waktu tempuh maksimal } 2 \text { jam } \\
-80 \mathrm{~km}-160 \mathrm{~km} \text { dengan waktu tempuh maksimal } 4 \text { jam } \\
->160 \mathrm{~km}\end{array}$ & $\begin{array}{l}\text { Rai dan Mahadewi, } \\
2012\end{array}$ \\
\hline & $\begin{array}{l}\text { Moda transportasi } \\
\text { umum }\end{array}$ & $\begin{array}{l}\text { - Dilalui moda transportasi umum } \\
\text { - Rute angkutan sudah dapat mengintegrasi objek-objek } \\
\text { pariwisata } \\
\text { - Jadwalnya tepat } \\
\text { - Tarifnya relatif, tidak terlalu mahal }\end{array}$ & $\begin{array}{l}\text { Spillane dalam Tahir, } \\
2005\end{array}$ \\
\hline \multirow[t]{2}{*}{ Kelembagaan } & $\begin{array}{l}\text { Lembaga } \\
\text { pengelola }\end{array}$ & $\begin{array}{l}\text { Objek pariwisata dikelola oleh } \\
\text { - Lembaga Pemerintah } \\
\text { - Swasta } \\
\text { - Organisasi masyarakat }\end{array}$ & $\begin{array}{l}\text { PP Nomor } 50 \text { Tahun } \\
2011 \quad \text { tentang } \\
\text { Rencana Induk } \\
\text { Pembangunan } \\
\text { Pariwisata Nasional } \\
\text { Tahun 2010-2025 }\end{array}$ \\
\hline & Promosi & $\begin{array}{l}\text { - Promosi dilakukan di semua media, baik cetak atau media } \\
\text { sosial } \\
\text { - Terdapat agen perjalanan wisata }\end{array}$ & Yoeti, 1996 \\
\hline $\begin{array}{l}\text { Partisipasi } \\
\text { masyarakat }\end{array}$ & $\begin{array}{l}\text { Partisipasi } \\
\text { masyarakat }\end{array}$ & $\begin{array}{l}\text { Peran masyarakat dalam mendukung kawasan wisata pantai, } \\
\text { meliputi } \\
\text { - Partisipasi dalam perencanaan } \\
\text { - Partisipasi dalam pengelolaan } \\
\text { - Partisipasi dalam evaluasi }\end{array}$ & Artiningsih, 2008 \\
\hline \multirow[t]{2}{*}{$\begin{array}{l}\text { Keramah- } \\
\text { tamahan }\end{array}$} & $\begin{array}{l}\text { Pelayanan pelaku } \\
\text { usaha }\end{array}$ & $\begin{array}{l}\text { Adanya perilaku yang ramah (baik, sopan) dari para pelaku } \\
\text { usaha kepada wisatawan. }\end{array}$ & Prawinata, 2016 \\
\hline & $\begin{array}{l}\text { Keamanan sosial } \\
\text { wisatawan }\end{array}$ & $\begin{array}{l}\text { Semakin sering terjadi tindak kriminal maka destinasi wisata } \\
\text { tersebut tidak aman } \\
\text { - Sering terjadi tindak kejahatan di destinasi pariwisata } \\
\text { (hampir setiap hari) }\end{array}$ & Susanti, 2010 \\
\hline
\end{tabular}




\begin{tabular}{|c|c|c|}
\hline Variabel & Indikator & Sumber \\
\hline & $\begin{array}{l}\text { - Pernah terjadi tindak kejahatan di destinasi pariwisata } \\
\text { (terjadi pada waktu-waktu tertentu) } \\
\text { - Tidak pernah terjadi tindak kejahatan di kawasan pariwisata }\end{array}$ & \\
\hline \multirow{2}{*}{$\begin{array}{l}\text { Keamanan } \\
\text { terhadap bencana } \\
\text { / Mitigasi bencana }\end{array}$} & $\begin{array}{l}\text { Semakin tinggi tingkat kerawanan bencana alam tsunami maka } \\
\text { semakin rendah nilainya } \\
\text { - Tingkat kerawanan bencana tinggi } \\
\text { - Tingkat kerawanan bencana sedang } \\
\text { - Tingkat kerawanan bencana rendah }\end{array}$ & Rosyidie, 2004 \\
\hline & $\begin{array}{l}\text { Mitigasi bencana secara non fisik dapat dilakukan dengan } \\
\text { pembuatan peraturan perundangan berupa norma standar } \\
\text { prosedur manual, sosialisasi upaya mitigasi bencana, menyusun } \\
\text { SOP untuk penyelamatan diri ataupun massal }\end{array}$ & Bappenas, 2006 \\
\hline
\end{tabular}

\subsection{Populasi dan Sampel}

a. Pengunjung

Pengunjung merupakan wisatawan yang datang ke objek wisata. Sampel untuk pengunjung menggunakan rumus Slovin, yaitu :

Keterangan

$$
n=\frac{N}{N(d)^{2}+1}
$$

$\mathrm{n}$ : Jumlah sampel yang dicari

$\mathrm{N}$ : Jumlah populasi

$\mathrm{d}$ : Tingkat akurasi (dalam penelitian ini sebesar $90 \%$ atau $\alpha=0,1$

Tabel 3. Jumlah Sampel Penelitian

\begin{tabular}{|l|c|c|}
\hline Objek Pariwisata Pantai & $\begin{array}{c}\text { Populasi (Jumlah } \\
\text { pengunjung per hari) }\end{array}$ & Sampel \\
\hline Pantai Jatimalang & 429 & 81 \\
\hline Pantai Keburuhan & 65 & 39 \\
\hline Pantai Ketawang & 234 & 70 \\
\hline
\end{tabular}

Sumber : Data Pengunjung Wisata Kabupaten Purworejo, 2016

b. Masyarakat

Masyarakat yang dimaksud pada penelitian ini adalah masyarakat yang tinggal di sekitar kawasan pariwisata pantai. Masyarakat pada tiap objek pariwisata pantai diambil secara purposive sampling. Responden dalam purposive sampling tidak ditentukan berupa jumlahnya namun pada pelaksanaan di lapangan, sampling dihentikan ketika informasi sudah jenuh atau terjadi pengulangan. Masyarakat yang dijadikan narasumber adalah tokoh masyarakat setempat seperti ketua RT, ketua RW, ketua paguyuban ataupun tokoh yang dituakan.

\section{c. Pemerintah}

Untuk pengambilan sampel pada pemerintah menggunakan purposive sampling. Purposive sampling lebih mengutamakan tujuan penelitian daripada sifat populasi. Pada penelitian bagian pemerintah terkait yaitu Dinas Pariwisata dan Kebudayaan; dan Kantor Desa.

\subsection{Teknik Analisis}

Teknik analisis yang digunakan adalah pembobotan dan skoring. Pembobotan ini digunakan untuk mengetahui tingkat pengaruh kepentingan variabel terhadap perkembangan pariwisata pantai. Pada pembobotan menggunakan metode ranking. Penentuan ranking dapat dilakukan secara langsung, misalnya aspek/variabel yang paling penting diberi nilai 1, kemudian aspek/variabel yang penting diberi nilai 2, dan begitu seterusnya. Penentuan bobot dapat dilakukan dengan rumus sebagai berikut (Selamat, 2015). 


$$
W j=\frac{(n-r j+1)}{\sum(n-r p+1) \ldots \ldots \ldots \ldots(\text { pers } 1)}
$$

Keterangan :

Wj : bobot normal untuk variabel ke $\mathrm{j}(\mathrm{j}=1,2, \ldots . \mathrm{n})$

$\mathrm{n}$ : banyaknya variabel yang dikaji

$p$ : variabel $(p=1,2, \ldots . n)$

rj : posisi ranking suatu variabel
*) Setiap variabel diberi bobot senilai $(n-r j+1)$ kemudian dinormalisasi dengan $\sum(n-r p+1)$

Penentuan ranking aspek berdasarkan dengan banyaknya ahli yang menyatakan bahwa aspek tersebut penting dalam perkembangan pariwisata pantai. Semakin banyak ahli yang menyatakan bahwa aspek tersebut penting maka bobot aspek tersebut semakin besar. Selain itu, dalam menentukan ranking aspek berdasarkan dengan urgensi dalam aspek pariwisata.

Tabel 4. Pembobotan

\begin{tabular}{|l|c|c|}
\hline \multicolumn{1}{|c|}{ Aspek } & Rangking Aspek & Bobot Aspek \\
\hline Atraksi wisata & 1 & 0,25 \\
\hline Infrastruktur Wisata & 2 & 0,21 \\
\hline Ketersediaan pelabuhan perikanan pantai & 7 & 0,03 \\
\hline Infrastruktur kebencanaan & 6 & 0,07 \\
\hline Aksesibilitas & 3 & 0,18 \\
\hline Kelembagaan & 4 & 0,14 \\
\hline Hospitality & 5 & 0,11 \\
\hline
\end{tabular}

Sumber : Febrianingrum, Sri Rahayu, dkk., 2017

Sedangkan untuk menentukan mana faktor yang mendorong, faktor yang menghambat, dan faktor moderat dalam perkembangan pariwisata pantai dengan menggunakan skoring terhadap setiap variabel berdasarkan indikator yang telah ditentukan. Untuk mengklasifikasikan setiap variabel termasuk faktor pendorong, faktor penghambat dan faktor moderat maka ditentukan rumus sebagai berikut.

$$
M=\frac{(\text { skor terbesar variabel } x \text { bobot variabel })-(\text { skor terkecil variabel } x \text { bobot variabel })}{\text { jumlah kelas }}
$$

Setiap aspek/variabel memiliki interval yang berbeda-beda dalam pengelompokkan faktor pendorong dan faktor penghambat dalam perkembangan pariwisata pantai.

Tabel 5. Klasifikasi Faktor Pendorong dan Penghambat

\begin{tabular}{|c|l|c|c|c|c|c|}
\hline No & Nama Aspek & Bobot & Rumus Interval & $\begin{array}{c}\text { Faktor } \\
\text { Penghambat }\end{array}$ & Faktor Moderat & $\begin{array}{c}\text { Faktor } \\
\text { Pendorong }\end{array}$ \\
\hline 1 & Atraksi wisata & 0,25 & $M=\frac{0,75-0,25}{3}$ & $\begin{array}{c}0,25 \leq \text { nilai } \leq \\
0,417\end{array}$ & $\begin{array}{c}0,417<\text { nilai } \leq \\
0,584\end{array}$ & $\begin{array}{c}0,584<\text { nilai } \leq \\
0,75\end{array}$ \\
\hline 2 & $\begin{array}{l}\text { Infrastruktur } \\
\text { wisata }\end{array}$ & 0,21 & $\begin{array}{c}M=\frac{16,167}{0,63-0,21} \\
3\end{array}$ & $\begin{array}{c}0,21 \leq \text { nilai } \leq \\
0,35\end{array}$ & $\begin{array}{c}0,35<\text { nilai } \leq \\
0,49\end{array}$ & $\begin{array}{c}0,49<\text { nilai } \leq \\
0,63\end{array}$ \\
\hline 3 & $\begin{array}{l}\text { Fasilitas } \\
\text { kebencanaan }\end{array}$ & 0,07 & $M=\frac{0,21-0,07}{3}$ & $\begin{array}{c}0,07 \leq \text { nilai } \leq \\
0,117\end{array}$ & $\begin{array}{c}0,117<\text { nilai } \leq \\
0,164\end{array}$ & $\begin{array}{c}0,164<\text { nilai } \leq \\
0,21\end{array}$ \\
\hline 4 & $\begin{array}{l}\text { Fasilitas } \\
\text { perikanan }\end{array}$ & 0,03 & $M=\frac{M=0,047}{3}$ & $\begin{array}{c}0,03 \leq \text { nilai } \leq \\
0,05\end{array}$ & $\begin{array}{c}0,05<\text { nilai } \leq \\
0,07\end{array}$ & $\begin{array}{c}0,07<\text { nilai } \leq \\
0,09\end{array}$ \\
\hline 5 & Aksesibilitas & 0,18 & $M=\frac{0,54-0,18}{3}$ & $\begin{array}{c}0,18 \leq \text { nilai } \leq \\
0,3\end{array}$ & $\begin{array}{c}0,3<\text { nilai } \leq \\
0,42\end{array}$ & $\begin{array}{c}0,42<\text { nilai } \leq \\
0,54\end{array}$ \\
\hline
\end{tabular}




\begin{tabular}{|c|l|c|c|c|c|c|}
\hline No & \multirow{2}{*}{ Nama Aspek } & Bobot & Rumus Interval & \multicolumn{3}{|c|}{ Klasifikasi faktor } \\
\cline { 5 - 7 } & & $\begin{array}{c}\text { Faktor } \\
\text { Penghambat }\end{array}$ & Faktor Moderat & $\begin{array}{c}\text { Faktor } \\
\text { Pendorong }\end{array}$ \\
\hline 6 & Kelembagaan & 0,14 & $M=\frac{0,42-0,14}{3}$ & $\begin{array}{c}0,14 \leq \text { nilai } \leq \\
0,23\end{array}$ & $\begin{array}{c}0,23<\text { nilai } \leq \\
0,33\end{array}$ & $\begin{array}{c}0,33<\text { nilai } \leq \\
0,42\end{array}$ \\
\hline 7 & Hospitality & 0,11 & $M=\frac{0,33-0,11}{3}$ & $\begin{array}{c}0,11 \leq \text { nilai } \leq \\
0,18\end{array}$ & $\begin{array}{c}0,18<\text { nilai } \leq \\
0,26\end{array}$ & $\begin{array}{c}0,26<\text { nilai } \leq \\
0,33\end{array}$ \\
\hline
\end{tabular}

Sumber : Febrianingrum, Sri Rahayu, dkk., 2017

Penjelasan:

1. Faktor penghambat merupakan faktor yang menjadi kelemahan dalam perkembangan pariwisata pantai karena kondisi elemen pariwisata yang kurang atau bahkan tidak ada sehingga memiliki nilai paling rendah.

2. Faktor moderat merupakan faktor dengan nilai yang sedang (berada di tengah, bukan faktor penghambat atau pendorong). Pada faktor moderat sudah terdapat elemen pariwisata namun masih ada yang diperbaiki agar dapat menjadi potensial untuk dikembangkan.

3. Faktor pendorong merupakan faktor yang potensial dalam mendukung perkembangan pariwisata pantai karena sudah terdapat elemen pariwisata dengan kondisi yang baik sehingga memiliki nilai tertinggi dalam penilaian. Pada faktor pendorong pun perlu ditingkatkan khususnya dalam segi kualitas agar semakin baik.

\section{HASIL DAN PEMBAHASAN}

Pantai Jatimalang, Pantai Keburuhan dan Pantai Katawang Indah merupakan pantai yang diarahkan sebagai pengembangan kawasan pariwisata Kabupaten Purworejo. Berdasarkan Rencana Induk Pengembangan Pariwisata Kabupaten Purworejo tahun 2013-2028, pengembangan pariwisata di bagian pesisir selatan diarahkan untuk pengembangan wisata alam dimana masing-masing pantai memiliki tema yang diunggulkan seperti Pantai Jatimalang dengan tema wisata kuliner, Pantai Keburuhan dengan tema wisata bahari dan Pantai Ketawang Indah dengan tema wisata edukasi. Berikut merupakan penjelasan masing-masing variabel terhadap perkembangan pariwisata pantai di Kabupaten Purworejo.

\subsection{Atraksi Wisata}

Pariwisata pantai didasarkan pada kombinasi sumber daya yang unik dimana pertemuan daratan dan lautan yang menjadikannya atraksi berupa pesisir, pemandangan yang indah, keanekaragaman hayati di darat dan laut, kebudayaan dan adat istiadat, makanan sehat serta infrastruktur yang baik (Sara, 2014).

\section{a. Jenis aktivitas}

Di Kabupaten Purworejo sendiri setiap desa wisata yang memiliki pantai tidak hanya mengandalkan pantai saja dalam daya tariknya namun juga aktivitas-aktivitas lain yang berada di kawasan pantainya berupa hutan cemara yang terletak di ketiga pantai dan kebun buah naga di Pantai Jatimalang. Selain itu, ada aktivitas olahraga yang dilakukan pada tepi pantai yang berupa senam bersama atau sekedar bermain bola pantai. Pada Pantai Ketawang Indah memiliki area outbond dan kebun binatang mini yang terdapat beberapa hewan yang didatangkan dari luar kawasan. Begitupun di Pantai Keburuhan terdapat kegiatan susur pantai yang dipandu oleh Kelompok Sadar Wisata setempat. Berbagai jenis aktivitas wisata terdapat pada pantai-pantai di Kabupaten Purworejo.

Adanya berbagai jenis aktivitas lain untuk menambah daya tarik wisata pantai agar dapat lebih berkembang lagi dan agar semakin banyak wisatawan yang datang. Variabel jenis aktivitas termasuk dalam kategori faktor moderat karena sebenarnya pariwisata pantai di Kabupaten Purworejo memiliki berbagai aktivitas sebagai atraksi wisata. Namun sayangnya sebagian pengunjung pantai didominasi oleh kalangan muda/remaja yang mana memanfaatkan pariwisata pantai hanya sekedar sebagai tempat refreshing menikmati pemandangan alam dan mencari spot foto yang menarik. Kurangnya promosi serta informasi membuat sebagian pengunjung tidak mengetahui bahwa ada jenis aktivitas lain yang tersedia di pantai tersebut sehingga menganggap bahwa hiburan di pantai hanya sebatas menikmati pemandangan. 


\section{b. Keanekaragaman Hayati}

Keanekaragaman hayati pantai ini termasuk flora dan fauna merupakan salah satu daya tarik wisata yang potensial. Apabila jenis dan jumlah flora fauna sedikit maka dapat mengindikasikan bahwa pantai tersebut sudah mengalami kerusakan sehingga dapat mengurangi daya tarik (Fandeli dalam Latupapua, 2011).

Flora dan fauna yang ada di pantai-pantai Kabupaten Purworejo rata-rata memiliki kesamaan. Pada ketiga pantai memiliki flora yang sama yaitu taman cemara. Taman cemara digunakan sebagai peneduh kawasan pantai. Kemudian di Pantai Ketawang Indah terdapat hutan nyamplung dan hutan minyak kayu putih yang berfungsi sebagai greenbelt. Untuk faunanya bermacam-macam yaitu burung, udang, kepiting air tawar, kerang dan ikan laut lainnya. Namun setiap pantai memiliki fauna dominan yang berbeda.

Berdasarkan pada analisis keanekaragaman hayati, pada pantai-pantai di Kabupaten Purworejo memiliki flora dan fauna dengan jenis yang beragam dan bermacam-macam namun hanya terdapat satu atau dua flora fauna yang paling dominan. Hal ini menunjukkan bahwa pantai di Kabupaten Purworejo masih cenderung alami karena masih banyak ditemukan flora fauna sehingga termasuk dalam kategori faktor moderat.

\subsection{Infrastruktur Wisata}

Wisatawan memerlukan infrastruktur/fasilitas wisata untuk memenuhi kebutuhannya selama berada di destinasi wisata sehingga kelengkapan fasilitas wisata dan kualitas pelayanan dalam fasilitas tersebut diperlukan untuk mendorong perkembangan pariwisata (Yoeti, 1996).

\section{a. Sarana Dasar Pariwisata}

Sarana dasar pariwisata berbagai macam sarana yang dibutuhkan selama berada di destinasi wisata. Sarana wisata disediakan oleh pengelola destinasi wisata tersebut. Pada sarana dasar wisata tidak hanya dinilai dari ketersediaan namun juga kualitas pelayanannya. Namun untuk kualitas pelayanan dinilai dari prespektif pengunjung. Berikut merupakan tabel ketersediaan sarana di pantai-pantai Kabupaten Purworejo.

Tabel 6. Sarana Dasar Pariwisata pada Pantai di Kabupaten Purworejo

\begin{tabular}{|l|l|c|c|c|}
\hline No & \multicolumn{1}{|c|}{ Nama Sarana } & Pantai Ketawang Indah & Pantai Jatimalang & Pantai Keburuhan \\
\hline 1 & Warung makan & $\sqrt{ }$ & $\sqrt{ }$ & $\sqrt{ }$ \\
\hline 2 & Loket & - & $\sqrt{ }$ & - \\
\hline 3 & Toilet & $\sqrt{ }$ & $\sqrt{ }$ & $\sqrt{ }$ \\
\hline 4 & Mushola & $\sqrt{ }$ & - & - \\
\hline 5 & Homestay/penginapan & $\sqrt{ }$ & - \\
\hline 6 & Pos keamanan & - & - & - \\
\hline 7 & Pos kesehatan/klinik & - & - & $\sqrt{ }$ \\
\hline 8 & ATM center & $\sqrt{ }$ & - & - \\
\hline 9 & Area parkir & $\sqrt{ }$ & \\
\hline 10 & Toko souvenir & & & \\
\hline
\end{tabular}

Sumber : Febrianingrum, Sri Rahayu, dkk., 2017

Dari hasil analisis karakteristik fisik, sarana pariwisata termasuk dalam faktor yang menghambat perkembangan pariwisata pantai. Hal ini dikarenakan masih ada beberapa sarana pariwisata yang belum terpenuhi, selain itu dalam hal kualitas sarana masih kurang. Walaupun dari segi fisik tersedia minimal 5 fasilitas namun kondisinya tidak terawat dan pelayanannya membutuhkan waktu yang lama.

\section{b. Prasarana Dasar Pariwisata}

Prasarana penunjang pariwisata juga diperlukan untuk memenuhi kebutuhan wisatawan selama berada di destinasi pariwisata. Prasarana dasar pendukung wisata terdiri atas: penyediaan air bersih, jaringan listrik, jaringan drainase, saluran persampahan, telekomunikasi (telepon umum). Untuk prasarana minimal yang tersedia di destinasi wisata yaitu dua prasarana meliputi jaringan air bersih dan jaringan listrik (Yoeti, 1996). 
Tabel 7. Prasarana Dasar Pariwisata Pada Pantai di Kabupaten Purworejo

\begin{tabular}{|l|l|c|c|c|}
\hline No & \multicolumn{1}{|c|}{ Nama Prasarana } & Pantai Ketawang Indah & Pantai Jatimalang & Pantai Keburuhan \\
\hline 1 & Jaringan air bersih & $\sqrt{ }$ & $\sqrt{ }$ & $\sqrt{ }$ \\
\hline 2 & Jaringan persampahan & $\sqrt{ }$ & $\sqrt{ }$ & $\sqrt{ }$ \\
\hline 3 & Jaringan listrik & $\sqrt{ }$ & - & - \\
\hline 4 & Jaringan drainase & - & $\sqrt{ }$ & $\sqrt{ }$ \\
\hline 5 & Jaringan telekomunikasi & $\sqrt{ }$ & \\
\hline
\end{tabular}

Sumber: Febrianingrum, Sri Rahayu, dkk., 2017

Berdasarkan tabel tersebut dapat dilihat bahwa ketersediaan prasarana penunjang pariwisata di masing-masing pariwisata pantai di Kabupaten Purworejo sama, namun dari segi kualitas dinilai berdasarkan prespektif pengunjung. Dari analisis karakteristik fisik khususnya prasarana pariwisata, dalam hal kualitas prasarana masih kurang. Misalnya untuk jaringan persampahan, walaupun di setiap pantai sudah memiliki tempat sampah namun masih terdapat sampahsampah yang berserakan sehingga menganggu pemandangan pantai. Begitu pun dengan jaringan listrik dan jaringan telekomunikasi, walaupun sudah tersedia di masing-masing pantai namun belum semua dapat menikmati pelayanan dari jaringan tersebut.

\subsection{Fasilitas Kebencanaan}

Menurut Ongkosongo, 2004 di daerah pantai, pesisir dan pulau-pulau kecil merupakan daerah yang rawan bencana alam seperti gempa, banjir pasang dan angin besar sehingga dibutuhkan fasilitas mitigasi bencana. Bencana yang mengancam kawasan pesisir pantai selatan tidak hanya gelombang tinggi, namun juga tsunami. Tingkat kerawanan yang berbeda-beda pada masing-masing pantai berpengaruh pada tingkat mitigasi bencana yang ada di pantai tersebut. Semakin tinggi tingkat kerawanan bencana tsunami maka seharusnya semakin lengkap pula fasilitas terkait dengan mitigasi bencana.

Faktor terkait fasilitas kebencanaan pada pantai di Kabupaten Purworejo termasuk dalam kategori faktor moderat. Walaupun tidak memiliki tingkat kerawanan bencana tsunami yang tinggi namun perlu diperhatikan fasilitas kebencanaannya karena pesisir selatan Pulau Jawa juga rawan akan gelombang tinggi. Setiap tahunnya terjadi gelombang tinggi yang tidak dapat diprediksi kapan waktu terjadinya dan dapat merusak infrastruktur yang ada di pantai. Hal ini bertujuan untuk mencegah adanya kerugian yang berupa kerugian fisik karena infrastrukur yang rusak ataupun kerugian berupa adanya korban jiwa.

\subsection{Fasilitas Pelabuhan Perikanan}

Sarana pelabuhan perikanan menjadi salah satu faktor yang berpengaruh terhadap perkembangan pariwisata pantai karena merupakan sarana dalam kegiatan pemanfaatan sumber daya pesisir dan laut yang berupa hasil perikanan tangkap. Pemanfaatan sumber daya pesisir dan laut ini menjadi penting karena berpengaruh terhadap perkembangan pembangunan kawasan sekitarnya (Stepantoro, 2000).

Variabel terkait fasilitas perikanan termasuk dalam kategori faktor penghambat karena tidak semua pantai memiliki sarana pelabuhan perikanan untuk mendukung aktivitas nelayan, hanya di Pantai Jatimalang dan di Pantai Keburuhan yang terdapat sarana pelabuhan perikanannya. Sedangkan untuk Pantai Ketawang Indah sendiri belum terdapat sarana pelabuhan perikanan. Padahal di pesisir selatan Kabupaten Purworejo, laut dimanfaatkan oleh masyarakat sebagai salah satu sumber mata pencaharian. Sebagian pekerjaan masyarakat yang tinggal di pesisir selatan adalah sebagai nelayan. Selain itu, pelabuhan perikanan juga menjadi salah satu daya tarik wisatawan karena wisatawan dapat melihat aktivitas nelayan saat kembali dari laut dan melihat atau bahkan membeli ikan-ikan hasil tangkapan laut.

\subsection{Aksesibilitas}

\section{a. Jaringan Jalan}

Salah satu faktor yang mendorong perkembangan pariwisata adalah jaringan jalan yang mana merupakan sirkulasi utama yang menghubungkan antar objek wisata sehingga memudahkan wisatawan menuju objek wisata tersebut 
(Wardhono, 2014). Jaringan jalan untuk pariwisata pantai di Kabupaten Purworejo meliputi kondisi jalan dan rambu penunjuk arah wisata.

Berdasarkan penjelasan tersebut menunjukkan bahwa jaringan jalan menjadi faktor pendorong untuk pariwisata pantai di Kabupaten Purworejo dalam kondisi baik dan didukung dengan rambu penunjuk arah yang baik, namun masih ada pantai yang belum memiliki akses yang baik untuk kendaraan roda 4 yaitu Pantai Keburuhan yang mana pada Pantai Keburuhan belum bisa dimasuki oleh kendaraan roda 4 sehingga apabila membawa kendaraan roda 4 diparkir jauh dari kawasan pantainya. Selain itu masih ada jalan yang berupa tanah pada Pantai Ketawang Indah.

\section{b. Posisi Geografis/Lokasi}

Posisi geografis destinasi wisata menjadi faktor yang mempengaruhi perkembangan pariwisata karena hal ini menjelaskan mengenai hubungan antara segmen pasar dan destinasi pariwisata. Semakin dekat jarak asal wisatawan dengan destinasi wisata maka mobilitasnya semakin tinggi karena mudah di jangkau (Rai dan Mahadewi, 2012). Untuk jarak dan waktu tempuh dari asal wisatawan menuju destinasi wisata berdasarkan pengunjung.

Asal lokasi wisatawan pun masih di sekitar Kabupaten Purworejo seperti dari Kabupaten Kebumen, Kabupaten Magelang, Kota Magelang dan Kabupaten Wonosobo. Walaupun dari luar kabupaten namun jaraknya yang tidak lebih dari $160 \mathrm{~km}$ dan waktu tempuhnya pun kurang dari 4 jam sehingga untuk lokasi wisata terhadap asal wisatawan masih dalam jangkauan sehinga pantai-pantai di Purworejo ini memiliki lokasi yang ideal berdasarkan jarak dan waktu tempuh wisatawan untuk dijadikan sebagai destinasi wisata.

\section{c. Moda Transportasi}

Transportasi umum mempengaruhi perkembangan dalam pariwisata karena merupakan ketersediaan jasa pelayanan transportasi untuk wisatawan menuju destinasi wisata. Suatu objek pariwisata kurang menarik apabila tidak ditunjang oleh transportasi untuk mencapainya. Unsur yang perlu terpenuhi dalam bidang tranportasi khususnya transportasi umum untuk menuju destinasi wisata (Spillane dalam Tahir, 2005) yaitu dilalui moda transportasi umum, rute angkutan sudah dapat mengintegrasi objek-objek pariwisata, jadwalnya tepat, tarifnya relatif, dan tidak terlalu mahal.

Di Kabupaten Purworejo sendiri belum terdapat transportasi umum yang menjangkau hingga ke destinasi wisata pantainya. Apabila menggunakan transportasi umum maka hanya dapat sampai di desa yang letaknya berada di sebelah utara dari ketiga desa wisata pantai. Hal ini cukup menyulitkan wisatawan yang tidak menggunakan kendaraan pribadi untuk dapat mencapai ke destinasi wisata pantai tersebut. Inilah mengapa moda transportasi merupakan salah satu faktor yang menjadi penghambat perkembangan pariwisata pantai di Kabupaten Purworejo.

\subsection{Kelembagaan}

\section{a. Lembaga Pengelola Pariwisata}

Pada pariwisata pantai di Kabupaten Purworejo seluruh pariwisata pantai yang juga termasuk dalam desa wisata ini dikelola oleh masyarakat yang tergabung dalam Kelompok Sadar Wisata (Pokdarwis). Secara umum, peran lembaga pengelola khususnya swasta belum terlihat. Selain itu, peran lembaga pemerintah sendiri juga masih kurang karena belum semua destinasi wisata pantai dikelola pemerintah. Hal ini menjadikan variabel terkait lembaga pengelola pariwisata menjadi faktor penghambat karena dalam pengelolaan belum melibatkan elemen pemerintah daerah dan lembaga swasta.

\section{b. Promosi Wisata}

Promosi wisata penting untuk menawarkan destinasi wisata kepada masyarakat umum agar mereka tertarik untuk mengunjungi destinasi wisata tersebut. Pariwisata di Kabupaten Purworejo dipromosikan dengan media sosial karena media sosial digunakan hampir oleh semua kalangan. 
Variabel promosi wisata termasuk dalam kategori menghambat karena belum terlihat adanya bentuk promosi lain selain dari media sosial. Padahal apabila ingin semakin berkembang, harus bisa memanfaatkan semua jenis media untuk melakukan promosi wisata. Untuk kedepannya diharapkan para pengelola dapat mengoptimalkan media promosi yang ada dan juga dapat menciptakan agen perjalanan sendiri. Hal itu bertujuan agar pariwisata pantai di Kabupaten Purworejo dapat lebih berkembang dan diketahui oleh banyak kalangan masyarakat. Apalagi jika memiliki agen perjalanan sendiri maka dapat mengenalkan destinasi wisata lainnya yang ada di Kabupaten Purworejo.

\section{c. Partisipasi Masyarakat}

Seluruh pariwisata pantai di Kabupaten Purworejo dikelola oleh Kelompok Sadar Wisata (Pok Darwis) yang merupakan organisasi masyarakat yang peduli akan potensi wisata di daerahnya. Pok Darwis ini memiliki peranan penting dalam perkembangan pariwisata pantai selama ini karena mereka yang mengelola pariwisata pantai itu sendiri, mulai dari memunculkan ide untuk menambah atraksi wisata hingga ke upaya usulan penambahan fasilitas yang diajukan ke pemerintah daerah.

\subsection{Keramahtamahan}

\section{a. Pelayanan Pelaku Usaha}

Sikap keramahan pelayanan pelaku usaha pada desa wisata pantai di Kabupaten Purworejo dilihat dari ketersediaan rumah makan karena rumah makan merupakan bentuk fasilitas yang disediakan untuk wisatawan dan dilayani langsung oleh masyarakat. Berdasarkan pendapat wisatawan, pelayanan yang diberikan sudah baik dan masyarakat lokal pun ramah dalam memberikan pelayanan serta kondisi tempat bersih. Namun beberapa pengunjung menilai dalam memberikan pelayanan, pengunjung memerlukan waktu yang cukup lama dalam menerima pelayanan tersebut karena jumlah wisatawan yang datang tidak sebanding dengan masyarakat sebagai pelaku usaha.

\section{b. Keamanan Sosial Wisatawan}

Selama kurun waktu 5 tahun terakhir, pariwisata pantai di Kabupaten Purworejo aman dari tindak kejahatan. Aman yang dimaksud yaitu tidak adanya tindak kejahatan yang terjadi seperti pencurian atau pemalakan. Hal ini menunjukkan bahwa tingkat keamanan wisatawan dari segi sosial baik sehingga menjadi faktor pendorong dalam perkembangan pariwisata pantai karena apabila destinasi wisata aman maka pengunjung merasa aman dan nyaman selama berwisata.

\section{c. Keamanan dari Segi Bencana Alam}

Pada desa wisata pantai di Kabupaten Purworejo sudah terdapat upaya mitigasi bencana berupa sosialisasi kepada masyarakat terkait dengan cara menyikapi apabila terjadi hal-hal yang tidak diinginkan berupa bencana alam. Namun sayangnya masih sebatas sosialisasi belum ada tindakan palatihan. Sudah ada upaya dalam mitigasi bencana namun tidak diikuti pelatihan tanggap bencana itu menjadikannya sebagai faktor moderat karena belum optimal dalam segi mitigasi bencana. Padahal upaya mitigasi bencana alam ditentukan oleh kemampuan petugas serta masyarakat setempat, teknologi, sarana prasarana, biaya serta kerjasama instansi terkait.

\subsection{Faktor Perkembangan Pariwisata Pantai di Kabupaten Purworejo}

Penentuan faktor yang menjadi pendorong, faktor yang menjadi penghambat dan faktor moderat pada pariwisata pantai di Kabupaten Purworejo diberi skor berdasarkan penilaian per variabel pada setiap aspek. Kemudian skor tersebut dikalikan dengan bobot sehingga menghasilkan nilai setiap variabel. Berikut merupakan tabel penilaian setiap variabel dalam perkembangan pariwisata pantai di Kabupaten Purworejo.

Tabel 8. Penilaian Tiap Variabel dalam Perkembangan Pariwisata Pantai di Kabupaten Purworejo

\begin{tabular}{|c|l|c|c|c|c|c|}
\hline Aspek & Variabel & Skor & Bobot & Nilai & Interval & Keterangan \\
\hline \multirow{3}{*}{ Atraksi wisata } & Jenis aktivitas & 1,81 & 0,25 & 0,45 & $\begin{array}{c}0,417<\text { nilai } \leq \\
0,584\end{array}$ & Faktor Moderat \\
\cline { 2 - 7 } & Keanekaragaman hayati & 2,16 & 0,25 & 0,54 & $\begin{array}{c}0,417<\text { nilai } \leq \\
0,584\end{array}$ & Faktor Moderat \\
\hline
\end{tabular}




\begin{tabular}{|l|l|c|c|c|c|l|}
\hline \multicolumn{1}{|c|}{ Aspek } & \multicolumn{1}{|c|}{ Variabel } & Skor & Bobot & Nilai & \multicolumn{1}{c|}{ Interval } & \multicolumn{1}{c|}{ Keterangan } \\
\hline \multirow{3}{*}{$\begin{array}{l}\text { Infrastruktur } \\
\text { Wisata }\end{array}$} & Sarana dasar pariwisata & 1,2 & 0,21 & 0,25 & $0,21 \leq$ nilai $\leq 0,35$ & $\begin{array}{l}\text { Faktor } \\
\text { Penghambat }\end{array}$ \\
\cline { 2 - 7 } & Prasarana pendukung pariwisata & 1 & 0,21 & 0,21 & $0,21 \leq$ nilai $\leq 0,35$ & $\begin{array}{l}\text { Faktor } \\
\text { Penghambat }\end{array}$ \\
\hline $\begin{array}{l}\text { Fasilitas } \\
\text { Kebencanaan }\end{array}$ & $\begin{array}{l}\text { Fasilitas terkait kebencanaan pada } \\
\text { kawasan pantai }\end{array}$ & 2 & 0,07 & 0,14 & $\begin{array}{c}0,117<\text { nilai } \leq \\
0,164\end{array}$ & Faktor Moderat \\
\hline $\begin{array}{l}\text { Fasilitas } \\
\text { Perikanan }\end{array}$ & Fasilitas pelabuhan perikanan pantai & 1,67 & 0,03 & 0,05 & $0,03 \leq$ nilai $\leq 0,05$ & $\begin{array}{l}\text { Faktor } \\
\text { Penghambat }\end{array}$ \\
\hline \multirow{4}{*}{ Aksesibilitas } & Jaringan jalan & 2,72 & 0,18 & 0,49 & $0,42<$ nilai $\leq 0,54$ & $\begin{array}{l}\text { Faktor } \\
\text { Pendorong }\end{array}$ \\
\cline { 2 - 7 } & Posisi geografis / lokasi & 2,74 & 0,18 & 0,49 & $0,42<$ nilai $\leq 0,54$ & $\begin{array}{l}\text { Faktor } \\
\text { Pendorong }\end{array}$ \\
\cline { 2 - 7 } & Moda transportasi & 1,33 & 0,18 & 0,24 & $0,18 \leq$ nilai $\leq 0,3$ & $\begin{array}{l}\text { Faktor } \\
\text { Penghambat }\end{array}$ \\
\hline \multirow{4}{*}{ Kelembagaan } & Lembaga pengelola & 1,33 & 0,14 & 0,19 & $0,14 \leq$ nilai $\leq 0,23$ & $\begin{array}{l}\text { Faktor } \\
\text { Penghambat }\end{array}$ \\
\cline { 2 - 7 } & Promosi & 1,44 & 0,14 & 0,2 & $0,14 \leq$ nilai $\leq 0,23$ & $\begin{array}{l}\text { Faktor } \\
\text { Penghambat }\end{array}$ \\
\cline { 2 - 7 } & Partisipasi masyarakat & 2,67 & 0,14 & 0,37 & $0,33<$ nilai $\leq 0,42$ & $\begin{array}{l}\text { Faktor } \\
\text { Pendorong }\end{array}$ \\
\hline \multirow{3}{*}{ Keramahtamahan } & Kelayanan pelaku usaha & 2,2 & 0,11 & 0,24 & $0,18<$ nilai $\leq 0,26$ & Faktor Moderat \\
\cline { 2 - 7 } & Keamanan wisatawan dari segi sosial & 2,67 & 0,11 & 0,29 & $0,26<$ nilai $\leq 0,33$ & $\begin{array}{l}\text { Faktor } \\
\text { Pendorong }\end{array}$ \\
\cline { 2 - 7 } & Keamanan terhadap bencana alam & 2 & 0,11 & 0,22 & $0,18<$ nilai $\leq 0,26$ & Faktor Moderat \\
\hline
\end{tabular}

Sumber: Febrianingrum, Sri Rahayu, dkk., 2017

Berdasarkan tabel 8 tersebut dapat diketahui bahwa faktor pendorong meliputi variabel jaringan jalan, kedekatan lokasi destinasi wisata terhadap asal wisatawan, partisipasi masyarakat dan keamanan sosial wisatawan. Untuk faktor yang menghambat perkembangan pariwisata pantai yaitu terkait dengan sarana dan prasarana pariwisata, fasilitas pelabuhan perikanan, moda transportasi pada kawasan wisata, peran lembaga pengelola pariwisata dan pemanfaatan media promosi. Sedangkan untuk faktor moderat meliputi adanya variasi dalam atraksi wisata, keanekaragaman hayati sebagai daya tarik wisata, pelayanan pelaku usaha, ketersediaan fasilitas kebencanaan pesisir dan tindakan mitigasi bencana pesisir pantai.

\section{KESIMPULAN}

Pantai-pantai di Kabupaten Purworejo memiliki potensi yang dapat dikembangkan sehingga pada masa yang akan datang diharapkan menjadi pariwisata andalan di Kabupaten Purworejo. Potensi yang dimiliki meliputi ketersediaan jaringan jalan yang baik sebagai kemudahan akses wisatawan mencapai destinasi wisata, kedekatan lokasi destinasi wisata terhadap asal wisatawan, peran masyarakat yang aktif untuk mendukung perkembangan pariwisata pantai, tingginya tingkat keamanan pada destinasi wisata sebagai bentuk perlakuan baik masyarakat lokal terhadap wisatawan.

Namun masih terdapat beberapa faktor kelemahan yang menjadi penghambat dalam mengembangkan pariwisata pantai di Kabupaten Purworejo. Faktor-faktor tersebut meliputi, keterbatasan pemenuhan sarana dasar pariwisata beserta pelayanannya, keterbatasan penyediaan prasarana penunjang pariwisata, ketidaklengkapan sarana pelabuhan perikanan untuk menunjang aktivitas masyarakat setempat, ketidakintegrasian moda transportasi umum antar pariwisata pantai, ketidakoptimalan peran lembaga pengelola pariwisata, ketidakoptimalan pemanfaatan media dalam promosi wisata.

Selain faktor pendorong dan faktor penghambat, terdapat pula faktor moderat. Faktor moderat ini juga harus diperhatikan karena apabila dibiarkan tanpa dikembangkan dapat menjadi masalah dan menghambat perkembangan pariwisata pantai di Kabupaten Purworejo. Faktor moderat ini meliputi adanya variasi atraksi wisata, keanekaragaman hayati sebagai daya tarik wisata, pelayanan baik pelaku usaha terhadap wisatawan, ketersediaan fasilitas kebencanaan pesisir dan tindakan mitigasi bencana pesisir pantai. 


\section{DAFTAR PUSTAKA}

Aristrawati, Ni Luh Putu. 2015. Tesis: Evaluasi Parade Ogoh-Ogoh Sebagai Pendukung Pengembangan Pariwisata Budaya di Kota Denpasar. Universitas Udayana.

Artiningsih, dkk. (2008). Peran Serta Masyarakat dalam Pengelolaan Sampah Rumah Tangga (Studi Kasus di Sampangan dan Jomblang, Kota Semarang). Jurnal IImiah UNTAG Semarang.

Bappenas. (2006). Rencana Aksi Nasional Pengurangan Resiko Bencana 2006-2009. Jakarta: Perum Percetakan Negara Republik Indonesia

KBBI Online Daring Edisi III. 2016. Website http://kbbi.web.id

Keputusan Menteri Kelautan dan Perikanan Nomor: Kep.10/MEN/2004 tentang Pelabuhan Perikanan.

Keputusan Menteri Permukiman dan Prasarana Wilayah No. 534/KPTS/M/2001 tentang Pedoman Standar Pelayanan Minimal Bidang Penataan Ruang, Perumahan Permukiman dan Pekerjaan Umum

Latupapua, Yosevita Th. (2011). Persepsi Masyarakat terhadap Potensi Objek Daya Tarik Wisata Pantai di Kecamatan Kei Kecil Kabupaten Maluku Tenggara. Jurnal Agroforesty ISSN, 1907-7556.

Mahagangga, N. L. 2015. Partisipasi Masyarakat Lokal Dalam Pariwisata (Studi Kasus di Desa Wisata Belimbing, Tabanan, Bali). Jurnal Destinasi Pariwisata Vol. 3 Nomor 1.

Prawinata, Adi. 2016. Pengaruh Keramahtamahan dan Kualitas Pelayanan Terhadap Kepuasan Pelanggan. Jurnal Administrasi Bisnis Vol. 32 No. 1.

Peraturan Menteri Pekerjaan Umum No. 40/PRT/M/2007 tentang Pedoman Perencanaan Tata Ruang Kawasan Reklamasi Pantai. Departemen Pekerjaan Umum.

Peraturan Pemerintah Nomor 34 Tahun 2006 tentang Jalan

Peraturan Pemerintah Nomor 50 Tahun 2011 tentang Rencana Induk Pariwisata Nasional Tahun 2011-2025

Perdana, Andrean. 2015. Pertumbuhan dan Perkembangan Serta Faktor yang Mempengaruhi website http://www.kompasiana.com/andre_manutd/pertumbuhan-dan-perkembangan-serta-faktor-yangmempengaruhinya-kd-2_550042d8a33311d372510659

Ongkosongo, O. S. R. 2004. Laporan Akhir Dinamika Dataran Pesisir Sayap Timur Teluk Jakarta: kaitannya dengan potensi pengembangan ekosistem wilayah pesisir. P2O-LIPI. Jakarta.

Rai, I.G. dan Mahadewi. (2012). Metodologi Penelitian Pariwisata dan Perhotelan. Yogyakarta: ANDI.

Rosyidie, Arief. 2004. Aspek Kebencanaan pada Kawasan Wisata. Jurnal Perencanaan Wilayah dan Kota, 15(2).

Sara, L. (2014). Pengelolaan Wilayah Pesisir : Gagasan Memelihara Aset Wilayah Pesisir dan Solusi Pembangunan Bangsa. Bandung: Alfabeta.

Selamat, Muhammad Banda. 2015. Modul Praktikum Sistem Informasi Geografis Jurusan Ilmu Kelautan Universitas Hasanudin. Diakses 22 Agustus 2017

http://repository.unhas.ac.id/bitstream/handle/123456789/7799/Pages\%20from\%20Pra

ktik\%20SIG\%202002\%20modul\%204.pdf;sequence=1)

Sugandi, D. 2011. Pengelolaan Sumberdaya Pantai. Gea.

Sunaryo, Bambang. (2013). Kebijakan Pembangunan Destinasi Pariwisata Konsep dan Aplikasinya di Indonesia. Yogyakarta: Gava Media.

Susanti, S. 2010. Mahasiswa Sebagai Duta Promosi Pariwisata Indonesia di Luar Negeri. Jurnal Pariwisata, 33.

Stepantoro, H.D. 2000. Penataan Ruang Kawasan Pesisir, Laut dan Pulau-pulau Kecil, serta Hubungan dengan Penataan Ruang Wilayah. Perencanaan Pembangunan.

Tahir, M. (2005). Pemanfaatan Ruang Kawasan Tepi Pantai Untuk Rekreasi Dalam Mendukung Kota Tanjung Pinang Sebagai Waterfront City. Tesis.

Wardhono, Fitria Indra. 2014. Pengembangan Pariwisata Bahari. Diakses 20 Oktober 2016 (http://www.slideshare.net/fitriwardhono/pengembangan-pariwisata-bahari)

Yoeti, Oka A. (1996). Pengantar Ilmu Pariwisata. Bandung: Angkasa. 